Article

\title{
Somatic Dimorphism in Cercariae of a Bird Schistosome
}

\author{
Miroslava Soldánová ${ }^{1, *(1)}$, Petra Kundid ${ }^{1,2}$, Tomáš Scholz ${ }^{1,2}$, Roar Kristoffersen ${ }^{3}$ and Rune Knudsen ${ }^{3}$ (i) \\ 1 Institute of Parasitology, Biology Centre of the Czech Academy of Sciences, \\ 37005 České Budějovice, Czech Republic; petra.kundid@paru.cas.cz (P.K.); tscholz@paru.cas.cz (T.S.) \\ 2 Department of Parasitology, Faculty of Science, University of South Bohemia in České Budějovice, \\ 37005 České Budějovice, Czech Republic \\ 3 Department of Arctic and Marine Biology, Faculty of Biosciences, Fisheries and Economics, UiT The Arctic \\ University of Norway, N9037 Tromsø, Norway; roar.kristoffersen@uit.no (R.K.); rune.knudsen@uit.no (R.K.) \\ * Correspondence: soldanova@paru.cas.cz
}

check for updates

Citation: Soldánová, M.; Kundid, P.; Scholz, T.; Kristoffersen, R.; Knudsen, R. Somatic Dimorphism in Cercariae of a Bird Schistosome. Pathogens 2022, 11, 290. https://doi.org/10.3390/ pathogens 11030290

Academic Editor: Sara V. Brant

Received: 17 January 2022

Accepted: 22 February 2022

Published: 24 February 2022

Publisher's Note: MDPI stays neutral with regard to jurisdictional claims in published maps and institutional affiliations.

Copyright: (C) 2022 by the authors. Licensee MDPI, Basel, Switzerland. This article is an open access article distributed under the terms and conditions of the Creative Commons Attribution (CC BY) license (https:// creativecommons.org/licenses/by/ $4.0 /)$.

\begin{abstract}
Phenotypic polymorphism is a commonly observed phenomenon in nature, but extremely rare in free-living stages of parasites. We describe a unique case of somatic polymorphism in conspecific cercariae of the bird schistosome Trichobilharzia sp. "peregra", in which two morphs, conspicuously different in their size, were released from a single Radix balthica snail. A detailed morphometric analysis that included multiple morphological parameters taken from 105 live and formalin-fixed cercariae isolated from several naturally infected snails provided reliable evidence for a division of all cercariae into two size groups that contained either large or small individuals. Large morph (total body length of 1368 and $1339 \mu \mathrm{m}$ for live and formalin-fixed samples, respectively) differed significantly nearly in all morphological characteristics compared to small cercariae (total body length of 976 and $898 \mu \mathrm{m}$ for live and formalin samples, respectively), regardless of the fixation method. Furthermore, we observed that small individuals represent the normal/commonly occurring phenotype in snail populations. The probable causes and consequences of generating an alternative, much larger phenotype in the parasite infrapopulation are discussed in the context of transmission ecology as possible benefits and disadvantages facilitating or preventing the successful completion of the life cycle.
\end{abstract}

Keywords: trematodes; cercariae; bird schistosome; Trichobilharzia; polymorphism; phenotype

\section{Introduction}

Phenotypic polymorphism is a commonly observed phenomenon in nature throughout the animal kingdom, arising from genetically based differentiation or phenotypic plasticity, or a combination of both (e.g., [1-4]). It is traditionally defined as an intraspecific variability in observable characteristics of an organism's trait, implying the co-occurrence of two or more distinct morphs of individuals (i.e., alternative phenotypes) in a population of the same species, inhabiting the same habitat at the same time $[5,6]$. Such phenotypic variability can be observed across morphological, developmental, behavioral, biochemical, and physiological traits. For instance, conspecific organisms within a given population may differ in body size, growth, reproduction, diet, habitat dispersal and use, and anti-predator behavior, primarily to improve the performance, overall productivity and thus persistence of the population [7]. Probably the best-known and classic examples are polymorphic casts in social insects with clear morphological adaptations to different roles [8] or sexual dimorphism in birds [9]. Many examples of intraspecific polymorphism are also found among uni- and multicellular parasites (e.g., [10-14]), which constitute a substantial proportion of global species diversity $[15,16]$.

Digenean trematodes represent a large and widespread parasitic group of helminths (Platyhelminthes: Neodermata) characterized by complex life cycles that involve sexual reproduction in the definitive host and clonal multiplication (or asexual reproduction 
by parthenogenesis, see [17]) in the first intermediate molluscan host [18]. The family Schistosomatidae includes mammalian and bird parasites (e.g., species of the most common genera Schistosoma and Trichobilharzia), which produce eggs that hatch in a first free-living larva- miracidium - in the aquatic environment $[19,20]$. After successful penetration of the suitable snail host (e.g., [21]), each invading miracidium gives rise to a generation of sporocysts, producing a large number of the second free-living dispersive stages-cercariae that are shed into the environment to infect a definitive host. As all individuals share the same genotype originating from a single miracidium, subsequent developmental stages including cercariae represent genetically identical individuals—clones $[17,18]$.

Much of the research on the morphological polymorphism in trematodes has been conducted on adult worms to better differentiate closely related taxa in taxonomic studies in the pre-molecular era (reviewed in [10,22]). The most intriguing example of an extreme somatic polymorphism in clonal trematode larval stages is the existence of reproductive and soldier redial castes differing in morphology and size, in addition to their function, behavior, and site location within the snail body (e.g., [23-25]). The use of experimental and/or genotyping molecular methods enabled phenotypic variation studies also in clonal cercariae such as output rates, activity and survival patterns, photo- and geotaxis behavior, or infection success [26-32]. As mammalian and bird schistosomes serve as model organisms for studying various biological and ecological aspects of parasitism and host-parasite interactions, research on their polymorphism is more advanced than in other trematode groups, focusing on host-induced morphometrical alterations (e.g., [33,34]), genetic diversity of different developmental stages (e.g., [35-39]), or a compatibility polymorphism in snail-schistosome interactions (reviewed in $[40,41]$ ). As far as we are aware, only one study to date has detected somatic dimorphism in larval schistosomes (cercariae of Schistosoma mansoni) during long-term breeding of the snail host (Biomphalaria glabrata) under laboratory conditions [42], but a similar case has not yet been reported for schistosome larvae infecting birds, originating from naturally infected snails. Hence, the presence of polymorphism in genetically identical individuals (clones) represents an interesting, but poorly understood biological phenomenon, which deserves future studies.

In this study, we report a unique case of somatic dimorphism in cercariae of a bird schistosome species isolated from a single naturally infected snail in a subarctic lake, which shed cercariae markedly differing from each other in body sizes. The aim is to document the existence of size-different cercarial morphs based on their morphometric characterization and comparisons of multiple morphological parameters of conspecific cercariae from a population of field-collected snails. The probable causes and consequences of generating an alternative phenotype in the parasite infrapopulation are discussed in the context of transmission ecology as possible benefits and disadvantages facilitating or preventing the successful completion of the life cycle.

\section{Results}

Molecular identification of the bird schistosome isolates sequenced from the single snail verified that both large and small morphs of cercariae belong to the same species Trichobilharzia franki haplotype "peregra" sensu Jouet et al. [43] (hereinafter referred to as Trichobilharzia sp. "peregra", see Materials and Methods). The two sequences were deposited in GenBank under accession numbers OM716986 (small morph) and OM716987 (large morph).

Biometric evaluations of 105 cercariae (38 live and 67 formalin-fixed), including the two size-different morphs and other Trichobilharzia sp. "peregra" cercariae isolated from naturally infected Radix balthica (Linnaeus, 1758) (Gastropoda: Lymnaeidae) within the snail population sampled in September 2013 (Figure 1, Table 1), showed differences in cercarial sizes with respect to fixation method (see Materials and Methods). Higher variability in morphometric data for specimens of live cercariae was due to the contracting and stretching nature of moving live cercariae compared to fixed dead larvae when photographed (Table 1; 
see also Appendix A Table A1 for metrical data for live specimens, and Table A2 for specimens fixed in hot formalin).
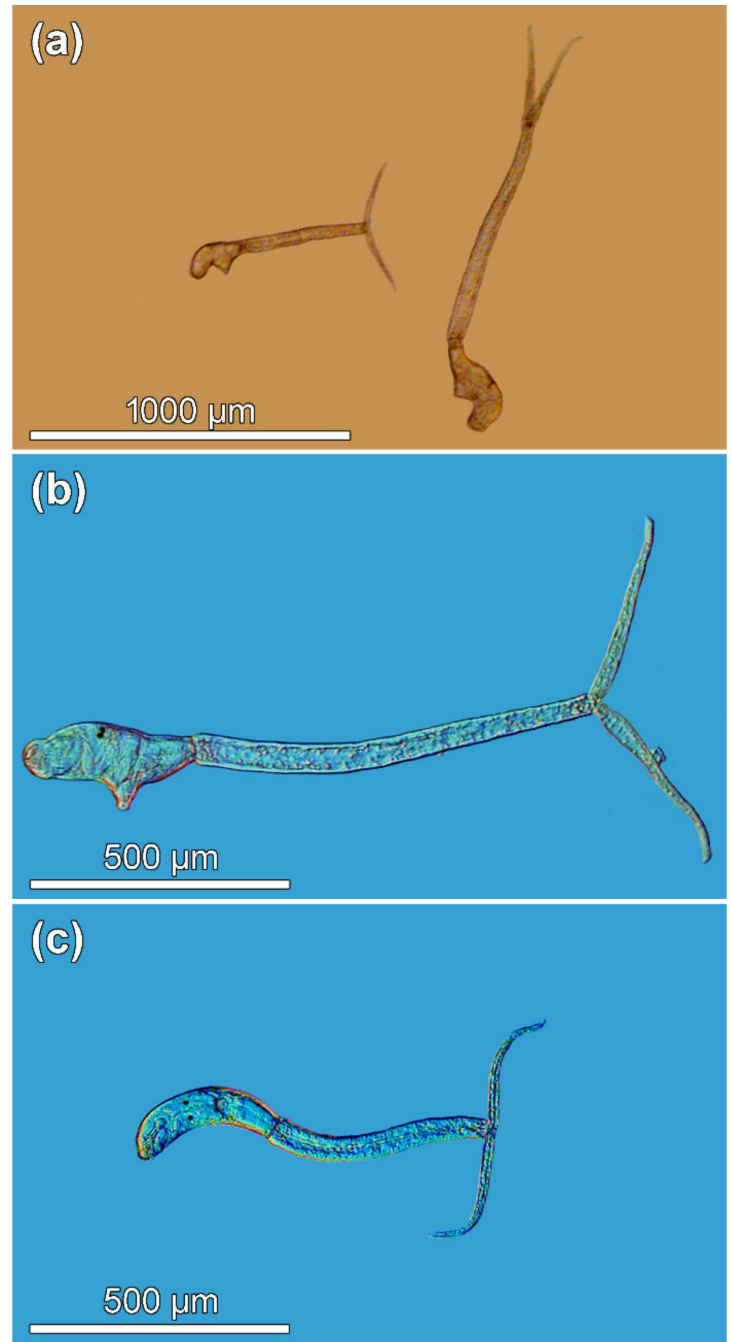

(d)

Figure 1. Trichobilharzia sp. "peregra", microphotographs of live cercariae. (a) Comparison of two distinct size morphs isolated from a single Radix balthica snail. (b) Large morph isolated from a single R. balthica snail individual. (c) Small morph isolated from a single R. balthica snail individual. (d) Cercaria representing individuals in the other small group isolated from four $R$. balthica snails that were obtained from the same collection in Lake Takvatn, Norway.

As for comparisons of cercarial dimensions among the three groups (large and small morphs, and other small cercariae; Table 1), the results of one-way ANOVA (analysis of variance) tests revealed significant differences in the majority of morphometric parameters, regardless of the fixation method (Table 2). 
Table 1. Comparison of measurements (means in micrometers) of cercariae of Trichobilharzia sp. "peregra" among groups of cercariae presented in this study (large and small morphs, and other small cercariae) with measurements of Jouet et al. [43].

\begin{tabular}{|c|c|c|c|c|c|c|c|}
\hline Snail Host & Radix peregra & Radix balthica & Radix balthica & Radix balthica & Radix balthica & Radix balthica & Radix balthica \\
\hline Source & Jouet et al. [43] & Present study & Present study & Present study & Present study & Present study & Present study \\
\hline Group of cercariae & - & $\begin{array}{l}\text { Large } \\
\text { morphs }\end{array}$ & $\begin{array}{c}\text { Small } \\
\text { morphs }\end{array}$ & $\begin{array}{l}\text { Other small } \\
\text { cercariae }^{2}\end{array}$ & $\begin{array}{c}\text { Large } \\
\text { morphs }\end{array}$ & Small morphs ${ }^{1}$ & $\begin{array}{l}\text { Other small } \\
\text { cercariae }^{2}\end{array}$ \\
\hline Fixation method & $\begin{array}{l}\text { Live and } \\
\text { formalin }\end{array}$ & Live & Live & Live & $\begin{array}{c}\text { Hot } \\
\text { formalin }\end{array}$ & $\begin{array}{c}\text { Hot } \\
\text { formalin }\end{array}$ & $\begin{array}{l}\text { Hot } \\
\text { formalin }\end{array}$ \\
\hline No. of cercariae measured & 31 & 7 & 8 & 23 & 9 & 16 & 42 \\
\hline Total length & 864 & 1368 & 994 & 970 & 1339 & 944 & 881 \\
\hline Body length & 257 & 340 & 276 & 272 & 278 & 241 & 223 \\
\hline Body width & 73 & 110 & 90 & 93 & 75 & 66 & 62 \\
\hline Tail stem length & 379 & 702 & 449 & 432 & 741 & 461 & 421 \\
\hline Tail stem width & 50 & 62 & 57 & 52 & 54 & 47 & 44 \\
\hline Furca length & 227 & 326 & 270 & 265 & 320 & 242 & 237 \\
\hline Head organ length & - & 119 & 93 & 97 & 85 & 74 & 73 \\
\hline Head organ width & - & 76 & 64 & 64 & 50 & 45 & 43 \\
\hline Diameter of acetabulum & 28 & 34 & 27 & 34 & 29 & 26 & 25 \\
\hline $\begin{array}{l}\text { Center of acetabulum to anterior } \\
\text { body end }\end{array}$ & 182 & 212 & 165 & 161 & 167 & 137 & 134 \\
\hline Diameter of eye spot & - & 9 & 8 & 7 & 9 & 8 & 8 \\
\hline Eye spot to anterior body end & 134 & 145 & 124 & 120 & 123 & 112 & 103 \\
\hline Body length/Body width & $3.52^{3}$ & 3.08 & 3.07 & 2.96 & 3.76 & 3.70 & 3.71 \\
\hline Body length/Tail stem length & $0.68^{3}$ & 0.49 & 0.62 & 0.65 & 0.38 & 0.52 & 0.54 \\
\hline Tail stem length/Furca length & $1.69^{3}$ & 2.17 & 1.67 & 1.62 & 2.32 & 1.91 & 1.78 \\
\hline
\end{tabular}

${ }^{1}$ Two distinct size morphs of cercariae isolated from one snail individual, ${ }^{2}$ Cercariae isolated from four snail individuals, and ${ }^{3}$ Calculated from the mean values in the original article.

Table 2. Results of separate one-way ANOVA (analysis of variance) tests for two data sets (live and formalin-fixed specimens) evaluating the differences in morphometrical parameters of cercariae of Trichobilharzia sp. "peregra" among three groups of cercariae (large and small morphs, and other small cercariae). Statistically significant results (at $\alpha=0.05)$ are indicated in bold. See Table 1 for the number of cercariae measured and entered into statistical analyses.

\begin{tabular}{ccccccccc}
\hline Data Set & \multicolumn{3}{c}{ Live Cercariae } & \multicolumn{3}{c}{ Formalin-Fixed Cercariae } \\
\hline Parameter Tested & Df ${ }^{\mathbf{1}}$ & $\mathbf{M S}^{\mathbf{2}}$ & $\mathbf{F}^{\mathbf{3}}$ & $\boldsymbol{p}^{\mathbf{4}}$ & $\mathbf{D f}$ & $\mathbf{M S}^{\mathbf{2}}$ & $\mathbf{F}^{\mathbf{3}}$ & $\boldsymbol{p}^{\mathbf{4}}$ \\
\hline Total length & 2 & 0.348 & 17.84 & $<\mathbf{0 . 0 0 1}$ & 2 & 0.656 & 153.1 & $<\mathbf{0 . 0 0 1}$ \\
Body length & 2 & 0.138 & 9.13 & $<\mathbf{0 . 0 0 1}$ & 2 & 0.189 & 21.3 & $<\mathbf{0 . 0 0 1}$ \\
Body width & 2 & 0.095 & 9.18 & $<\mathbf{0 . 0 0 1}$ & 2 & 0.147 & 8.49 & $<\mathbf{0 . 0 0 1}$ \\
Tail stem length & 2 & 0.713 & 16.11 & $<\mathbf{0 . 0 0 1}$ & 2 & 1.210 & 115.7 & $<\mathbf{0 . 0 0 1}$ \\
Tail stem width & 2 & 0.106 & 3.14 & 0.056 & 2 & 0.129 & 13.30 & $<\mathbf{0 . 0 0 1}$ \\
Furca length & 2 & 0.123 & 8.63 & $<\mathbf{0 . 0 0 1}$ & 2 & 0.343 & 45.6 & $<\mathbf{0 . 0 0 1}$ \\
Head organ length & 2 & 0.137 & 18.17 & $<\mathbf{0 . 0 0 1}$ & 2 & 0.093 & 11.5 & $<\mathbf{0 . 0 0 1}$ \\
Head organ width & 2 & 0.086 & 12.27 & $<\mathbf{0 . 0 0 1}$ & 2 & 0.074 & 10.94 & $<\mathbf{0 . 0 0 1}$ \\
Diameter of acetabulum & 2 & 0.153 & 4.36 & $<\mathbf{0 . 0 5}$ & 2 & 0.075 & 6.17 & $<\mathbf{0 . 0 1}$ \\
Diameter of eye spot & 2 & 0.216 & 9.52 & $<\mathbf{0 . 0 0 1}$ & 2 & 0.160 & 11.31 & $<\mathbf{0 . 0 0 1}$ \\
Center of acetabulum to anterior body end & 2 & 0.093 & 13.55 & $<\mathbf{0 . 0 0 1}$ & 2 & 0.086 & 14.33 & $<\mathbf{0 . 0 0 1}$ \\
Eye spot to anterior body end & 2 & 0.101 & 5.99 & $<\mathbf{0 . 0 1}$ & 2 & 0.137 & 12.93 & $<\mathbf{0 . 0 0 1}$ \\
Body length/Body width & 2 & 0.005 & 0.57 & 0.570 & 2 & 0.001 & 0.06 & 0.94 \\
Body length/Tail stem length & 2 & 0.030 & 6.68 & $<\mathbf{0 . 0 1}$ & 2 & 0.046 & 17.39 & $<\mathbf{0 . 0 0 1}$ \\
Tail stem length/Furca length & 2 & 0.101 & 13.08 & $<\mathbf{0 . 0 0 1}$ & 2 & 0.121 & 32.25 & $<\mathbf{0 . 0 0 1}$ \\
\hline
\end{tabular}

${ }^{1}$ Degrees of freedom, ${ }^{2}$ Means of squares, ${ }^{3}$ Test criterion value, and ${ }^{4}$ Level of significance.

The subsequent pairwise post hoc Tukey's HSD (honestly significant difference) tests detected considerably larger cercariae in the large group compared to those cercariae in both small size groups (most $p<0.05$ ), while there were no significant differences in most measurements between small morphs and other small cercariae (most $p>0.05$ ). The most pronounced size differences between large and small cercariae are especially evidenced by four main length parameters (Figure 2), with a considerably greater total length by 374-458 $\mu \mathrm{m}$ (range of mean values), body length by 37-68 $\mu \mathrm{m}$, tail stem length by 253-320 $\mu \mathrm{m}$, and furca length by $56-83 \mu \mathrm{m}$, depending on the fixation (Table 1, Appendix A Tables A1 and A2). However, some body dimensions differed from this commonly observed 
pattern, being variable between live and formalin-fixed specimens (post hoc tests; two and six parameters, respectively). For live specimens, the diameter of acetabulum in large morph was greater than that in small morph only $(p<0.05)$. Simultaneously, small morph had much smaller acetabulum compared to other small cercariae $(p<0.05)$. Furthermore, large cercariae had significantly greater distance between the eye spot and the anterior body end compared to cercariae in the other small group $(p<0.01)$. For formalin-fixed samples, small morphs were significantly longer than other small cercariae in total, body and tail stem length (Figure $2 \mathrm{~b}$ ), and tail stem length to furca length ratio (all $p<0.05$ ). Furthermore, significantly greater body width and the distance measured from the eye spot to anterior body end were detected only for large cercariae when compared with other small cercariae (both $p<0.001$ ), the latter parameter being also longer in cercariae in the small group than in the other small cercariae $(p<0.05)$.

(a)

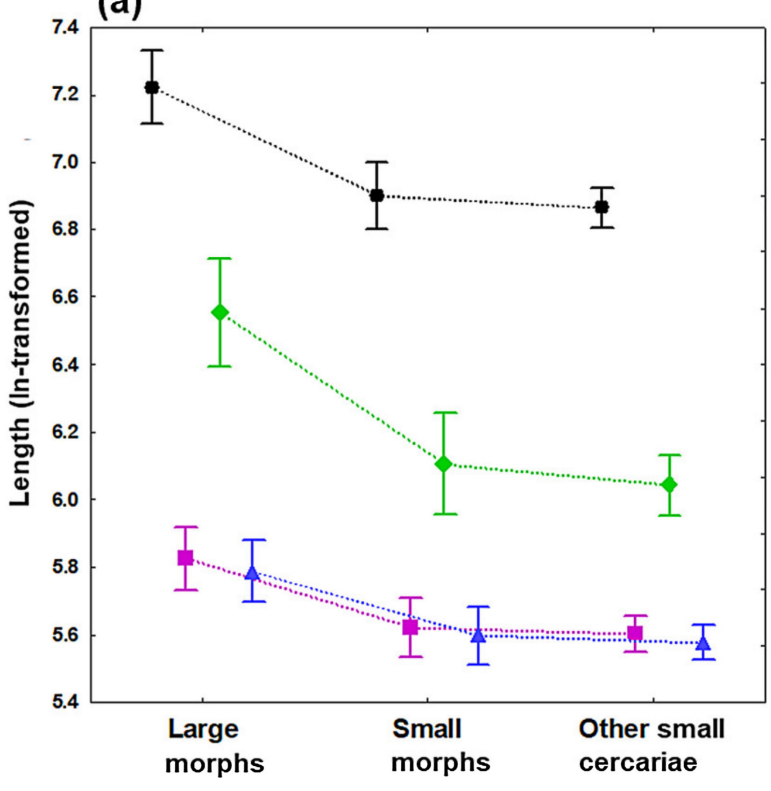

(b)

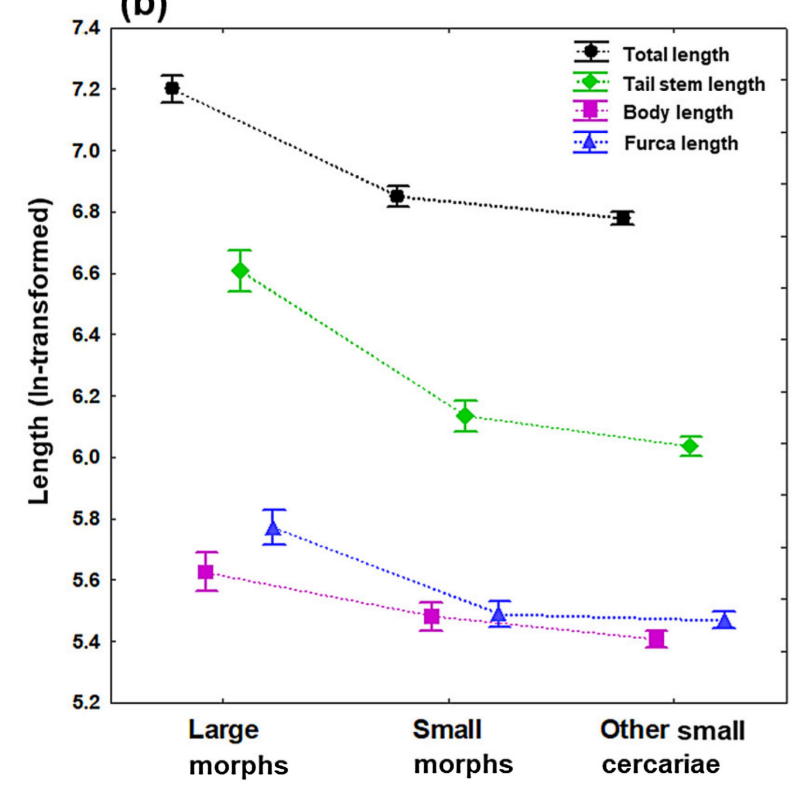

Figure 2. Length of four main body dimensions of cercariae of Trichobilharzia sp. "peregra" (differentiated by colors and symbols: total length in black and circles; body length in violet and squares; tail stem length in green and diamonds, furca length in blue and triangles). Measurements are based on (a) live specimens and (b) formalin-fixed specimens categorized into three groups: large and small morphs isolated from a single Radix balthica snail individual, and other small cercariae isolated from four $R$. balthica snail individuals (see Table 1 for the number of measured specimens). Symbols denote the mean values and vertical bars 0.95 confidence intervals.

Small cercariae in our study, especially those isolated from the additional four snails, correspond in their measurements to dimensions of T. franki haplotype "peregra" cercariae reported by Jouet et al. [43] (Table 1). However, cercariae in both these small groups differ in the total length about 106-130 $\mu \mathrm{m}$ (range of mean values) for live isolates and about $17-80 \mu \mathrm{m}$ for formalin-fixed isolates, mainly due to a much longer tail stem and furcae in our samples. The remaining parameters are slightly larger, slightly smaller, or overlapping in measurements, the variation depending on the fixation method (Table 1).

Overall, the above results for both live and formalin-fixed specimens of Trichobilharzia sp. "peregra" demonstrate that analyzed cercariae, which were initially categorized into three groups based on their origin from snails and size, form just two size categories, one of large individuals (average total body length of 1368 and $1339 \mu \mathrm{m}$ for live and formalin-fixed samples, respectively) and the second of small individuals (average total body length of 976 and $898 \mu \mathrm{m}$ for live and formalin samples, respectively). 


\section{Discussion}

In the present study, we demonstrated a phenotypic somatic dimorphism in cercariae of the bird schistosome Trichobilharzia sp. "peregra" shed from a single lymnaeid R. balthica snail individual. To our knowledge, this is a unique polymorphism case reported for cercariae of bird schistosomes, the second case in schistosomes (Pino et al. [42] documented size polymorphism in cercariae of the mammalian Schistosoma mansoni shed by laboratoryreared snail hosts) and one of very few reports of this extremely rare phenomenon in trematode larvae (e.g., [23-25]).

Our comparative morphometric analysis of clonal cercariae of the same T. franki haplotype "peregra" sensu Jouet et al. [43] provides reliable evidence for the division of cercariae into two size categories containing either large or small individuals, the former showing significantly higher values for most measured morphological characteristics. While examining patent infections, cercariae of the large morphotype were observed emerging in smaller quantities. This, together with similar dimensions of cercariae of T. franki haplotype "peregra" published by Jouet et al. [43], although from geographically distant regions (France and Iceland), leads to the assumption that all small individuals produced from a single snail and from the other four snails represent the normal/commonly occurring phenotype in natural snail populations. This is further supported by the fact that only cercariae corresponding to the small morph were always observed in our extensive collection of snails in Lake Takvatn between 2012 and 2019, during which we processed more than 4200 R. balthica across different seasons and found 85 patent infections with Trichobilharzia sp. "peregra" (see subsets of live cercariae of Trichobilharzia sp. "peregra" about $940 \mu \mathrm{m}$ long in Born-Torrijos et al. [44,45]).

Free-living cercariae are highly important stages in the transmission process between intermediate and definitive hosts [46-48], but the probability of reaching the next host is low due to various abiotic and biotic barriers lurking in an aquatic environment (e.g., $[49,50])$. Like many other trematodes, schistosomes use multiple strategies to increase contact with their bird hosts through cercariae-specific swimming and dispersal behavior, synchronized emergence with peak activity of birds, and responses to host cues [51-54]. The presence of large cercarial morphs within the bird schistosome infrapopulation may have some additional benefits for the trematode transmission to their definitive host. Firstly, larger individuals likely possess larger penetration glands with a higher volume of histolytic enzymes, which can lead to faster skin penetration and tissue invasion of a bird host. Secondly, large cercariae may remain active longer and thus prolong their survival in the aquatic environment. Cercariae are non-feeding larvae with a lifespan strongly dependent on the non-renewable glycogen reserves, which continuously decreases as cercariae age $[55,56]$. Glycogen is primarily stored in the main locomotion organ important for swimming and dispersal—-the tail [57], which contains about half of its total amount [58]. Large cercariae in our study had a tail slightly more than half as long as small morphs, suggesting a greater quantity of glycogen available to potentially extend cercarial survival. In contrast, larger cercariae generally swim faster by more intense movements [57], which results in a faster depletion of glycogen. Increased survival is directly associated with a longer active period, during which cercariae are most infectious to their hosts within a few hours after their emergence from snail hosts [56,59-61]. Thus, somatic dimorphism in cercariae may play an important role in the transmission ecology of trematodes in terms of infection success.

In contrast, there are also certain disadvantages for the transmission associated with local ecosystem biodiversity in a form of dilution effect of parasite infective stages that leads to a reduction in parasite population size [50,62-65], including dilution of bird schistosomes [66]. In Lake Takvatn, cercariae of Trichobilharzia sp. "peregra" are extensively consumed by invertebrate and vertebrate non-host predators at overall higher consumption rates compared to other trematode taxa $[44,45]$. The greater vulnerability to predation has been attributed to the dispersion strategy and much larger body of Trichobilharzia sp. "peregra" cercariae, as also documented for other predator-prey-parasite interactions 
(e.g., [67-70]). Therefore, generating an alternative phenotype, which may benefit from owning a large body potentially facilitating transmission of cercariae, can be at the same time substantially mitigated.

Phenotypic polymorphism may arise from genetic polymorphism, meaning a change in gene expression or use, where the phenotype of each individual is genetically determined, or from phenotypic plasticity, where the phenotype reacts flexibly to environmental stimuli, allowing organisms to adapt and survive in changing environment. A mixed strategy of development combines both mechanisms, where the phenotype is randomly assigned during development, possibly as a result of epigenetic modifications (e.g., [1-4,71]).

The effect of phenotypic plasticity on the development of large cercarial morphs of Trichobilharzia sp. "peregra" inside a snail individual could have been induced by a host environment (snail size) or an external environment acting on the host (the temperature). The effect of snail size on dimensions of cercariae, when larger snails produced larger cercariae, has been demonstrated in different snail-mammalian schistosome systems [72,73], but no such relationship has been observed for cercariae of three species of Trichobilharzia [74]. Moreover, the snail releasing two morphs was of only slightly more than medium size (length $\times$ width; $14.2 \times 9.2 \mathrm{~mm}$ ) within a group of all 15 infected snails releasing Trichobilharzia sp. "peregra" cercariae (mean length $\pm \mathrm{SD} \times$ mean width $\pm \mathrm{SD}$ in $\mathrm{mm} ; 12.8 \pm 2.4 \times 7.8 \pm 1.4$; range length $\times$ range width in $\mathrm{mm} ; 8.2-16.5 \times 5.3-10.0)$. The intramolluscan development of trematodes is strongly temperature-dependent, accelerating with increasing temperature [75]. The prepatent period (i.e., the time before cercariae emerge from a snail host) of bird schistosomes can range from 3 to 10 weeks $[53,76]$ during which larval stages are indirectly exposed to seasonally changing water conditions, which also may potentially result in the formation of an alternative phenotype. However, the less pronounced seasonal fluctuations in water temperature during the parasite's prepatent period at high latitudes (i.e., $13{ }^{\circ} \mathrm{C}$ in August, $8-10{ }^{\circ} \mathrm{C}$ in September in Lake Takvatn) compared to temperate ecosystems would likely have a mild effect of these host- and abiotic-related factors.

Cercariae of a given species are considered to be clones carrying identical genetic information if issued from a single miracidium. However, even these monomiracidial infections may demonstrate a substantial genetic interclonal (i.e., between clones isolated from different snails) and some levels of intraclonal variability (i.e., within clones isolated from a single snail) $[35,37,38,77,78]$. The latter variability has been suggested to have asexual origin, as it can occur only during parthenogenesis [79]. While this variability could be a possible explanation for the formation of two size morphs Trichobilharzia sp. "peregra" found in the present study, differences in phenotypic characteristics of cercariae such as morphology and behavior were found conspicuous at the interclonal level [27,28]. It implies that only one phenotype is likely generated under the scenario of monomiracidial infection. There was a relatively high prevalence of the bird schistosome in our study system (5.7\%) compared with other systems (usually less than $1 \%$, [53]) that may indicate multimiracidial infection of single snail releasing two morphs in Lake Takvatn, as noted elsewhere (e.g., [80,81]). Hence, the most probable explanation for occurrence of such conspicuously different morphs is the simultaneous development of two miracidia originating from different bird hosts in the same snail.

Nevertheless, the aforementioned mechanisms still would not explain the extremely rare frequency in the occurrence of large morphs in schistosomes. More likely, random processes occurring during the development of adult bird schistosomes in definitive bird hosts are the cause of somatic dimorphism rather than genetic polymorphism or phenotypic plasticity. However, it is difficult to draw any definite conclusion, especially given the clear aim of our study and the enormous complexity of internal and external factors influencing trematode development at all life cycle levels. This paper documents the first case of phenotypic polymorphism in clonal cercariae of schistosomes observed in a naturally infected snail host. Future studies should focus on elucidating ecological 
and evolutionary importance of this unique biological phenomenon that has been rarely documented in trematodes.

\section{Materials and Methods}

\subsection{Sample Collection and Species Identification}

In early September 2013, a total of 280 R. balthica were randomly collected by hand in the littoral zone of Lake Takvatn located in northern Norway $\left(69^{\circ} 07^{\prime} \mathrm{N}, 19^{\circ} 05^{\prime} \mathrm{E}\right)$. Patent (cercarial release) and prepatent (intramolluscan stages-sporocysts) infections with bird schistosomes were examined in laboratory according to Soldánová et al. [82].

A total of 16 snails $(5.7 \%)$ harbored larvae of bird schistosomes, all but one releasing cercariae. While examining patent infections, two distinct morphotypes of bird schistosome cercariae, which differed conspicuously in body size but seemingly not in their morphology, were observed emerging from a single snail individual (Figure 1a-c). To verify the identity of the larvae (and to eliminate possible double infection) isolated from a single snail individual in our study, cercariae of both size morphs were carefully separated and fixed in molecular grade ethanol for DNA isolation and sequencing. Following the protocol of sequencing analysis of bird schistosomes based on two internal transcribed spacers (ITS1 and ITS2) of the rRNA gene, molecular data revealed that the two newly generated sequences are identical to each other and to sequences for the T. franki haplotype "peregra" previously found in Lake Takvatn [82], confirming that both cercarial morphotypes belong to the same species. Additionally, four infected R. balthica individuals were randomly selected to obtain cercariae for morphometric comparison with the two morphs. These cercariae were visually inspected as small individuals (Figure 1d) and identified as T. franki haplotype "peregra" sensu Jouet et al. [43] based on molecular characterization of specimens from two of these four snails [82] or that cercariae obtained from the remaining two snails come from the same sampling conducted in September 2013 and only one schistosome so far occurred in the lake $[44,45,82]$. However, given the current knowledge of Trichobilharzia systematics with Trichobilharzia franki Müller \& Kimmig, 1994 parasitizing its type snail host Radix auricularia (Linnaeus, 1758) [43,83-85], T. franki haplotype "peregra" in R. balthica from lake Takvatn represents previously undescribed species [82] and is therefore referred to as Trichobilharzia sp. "peregra".

\subsection{Morphometric Characterization}

Cercariae of Trichobilharzia sp. "peregra" produced by the single snail shedding two morphs as well as those obtained from additional four snails were fixed in hot $4 \%$ formaldehyde solution (formalin) for metrical characterization and subsequent comparative analyses, in addition to measuring live cercariae. In this study, both live and formalin-fixed cercariae of Trichobilharzia sp. "peregra" were used to provide comparative data to describe the present case of somatic dimorphism. A total of 105 cercariae (38 live and 67 formalinfixed) were photographed with a digital camera of an Olympus BX51 microscope (Olympus Optical Co., Ltd., Tokyo, Japan). Measurements (in micrometers) were then taken from photographs using the program ImageJ [86]. In total, 12 morphometric body characteristics were measured and three ratio parameters were calculated based on body dimensions, i.e., the body length in relation to the body width, body length in relation to the tail stem length, and the tail stem length in relation to the furca length (Table 1).

To demonstrate the existence of somatic dimorphism in conspecific cercariae, dimensions were compared between the large and small morphs that were released from the same snail individual; dimensions of other cercariae from four other snails were used as a comparative population. Hence, all cercariae were categorized into three groups prior statistical analyses as follows: (i) large morph (isolated from a single snail; Figure 1b), (ii) small morph (isolated from a single snail; Figure 1c), and (iii) other small cercariae (isolated from other four snails; Figure 1d). The material of both live and fixed cercariae in each group originated from the same set of snails. The first visual data inspection indicated two sizes of cercariae comprising either large or small specimens (Figure 1a-d), which was 
furthermore supported by the bimodal shape of data based on the frequency distribution of cercarial total length (Figure 1 and Appendix A Figure A1). The above-mentioned division of cercariae into three "size" groups was made to avoid bias caused by pooling small cercariae from four additional snails with relatively few cercariae of small morph isolated from the single snail. The ideal scenario would be to use an equal number of specimens in each group, but the snail shedding both size morphs died soon after the parasite's identification, photographing, and fixation of cercariae. Measurements obtained in our study were compared with dimensions of $T$. franki haplotype "peregra" cercariae published by Jouet et al. [43].

To evaluate data statistically, we first tested whether the live and formalin-fixed specimens can be merged together to increase the number of specimens in our dataset. A paired sample $t$-test performed on the total length of cercariae (ln-transformed) was used in analyzing differences between live and fixed material in each corresponding size group. While no significant differences were detected for large morphs $(\mathrm{t}=1.163, \mathrm{df}=14, p>0.05)$, formalin-fixed cercariae were significantly smaller than live specimens in both groups of small cercariae (small morphs, $\mathrm{t}=2.312, \mathrm{df}=22, p<0.05$; other small cercariae, $\mathrm{t}=2.788$, $\mathrm{df}=63, p<0.01$; compare means of total length in Table 1). Therefore, live and formalinfixed specimens were analyzed separately in a series of univariate comparisons by analyses of variance (one-way ANOVAs) to assess differences in cercarial sizes among the three size groups of cercariae. Post hoc Tukey's HSD tests were performed to detect differences in individual morphometrical characters among pairs of cercarial groups. Morphometric data of all 12 body characteristics as well as three ratio parameters were used in both data sets, but only the total length and lengths of the body, tail stem, and furca are displayed graphically. As the main goal of this study is to demonstrate the existence of morphological dimorphism between cercarial clones, we believe that the simple comparison based on separate ANOVA analyses, together with four length parameters selected for better illustration, best describe the intraspecific somatic variability in Trichobilharzia sp. "peregra" cercariae. All analyses are based on ln-transformed measurements and carried out using Statistica 7.0 software package (StatSoft Inc., Tulsa, OK, USA) with significance levels set at 0.05 .

Author Contributions: Conceptualization, M.S.; Formal analysis, M.S.; Funding acquisition, T.S., R.K. (Roar Kristoffersen) and R.K. (Rune Knudsen); Investigation, M.S., R.K. (Roar Kristoffersen), and R.K. (Rune Knudsen); Methodology, M.S. and P.K.; Supervision, M.S.; Visualization, M.S.; Writing—original draft, M.S.; and Writing—review and editing, M.S., P.K., T.S., R.K. (Roar Kristoffersen) and R.K. (Rune Knudsen). All authors have read and agreed to the published version of the manuscript.

Funding: Institute of Parasitology, Biology Centre of the Czech Academy of Sciences (RVO: 60077344) (Miroslava Soldánová, Petra Kundid, Tomáš Scholz), and UiT The Arctic University of Norway and the Research Council of Norway (no. 213610) (Roar Kristoffersen, Rune Knudsen).

Institutional Review Board Statement: Not applicable.

Informed Consent Statement: Not applicable.

Data Availability Statement: Sequence data reported in this paper are available in the GenBank under accession numbers OM716986, OM716987. Data supplemental to the main text are provided in Appendix A. Raw and processed data can be shared on reasonable personal request directly from the corresponding author.

Acknowledgments: We are grateful to Laina Dalsbø, Karin Strand Johannessen, Eirik H. Henriksen and Per-Arne Amundsen (UiT The Arctic University of Norway) for their assistance during field collection. We thank to Simona Georgieva for generating sequences of cercarial isolates, Caroline Kibet and Jan Brabec for alignments, and Blanka Škoríková for technical assistance with figures (Institute of Parasitology, Biology Centre CAS, Czech Republic).

Conflicts of Interest: The authors declare no conflict of interest. 


\section{Appendix A}
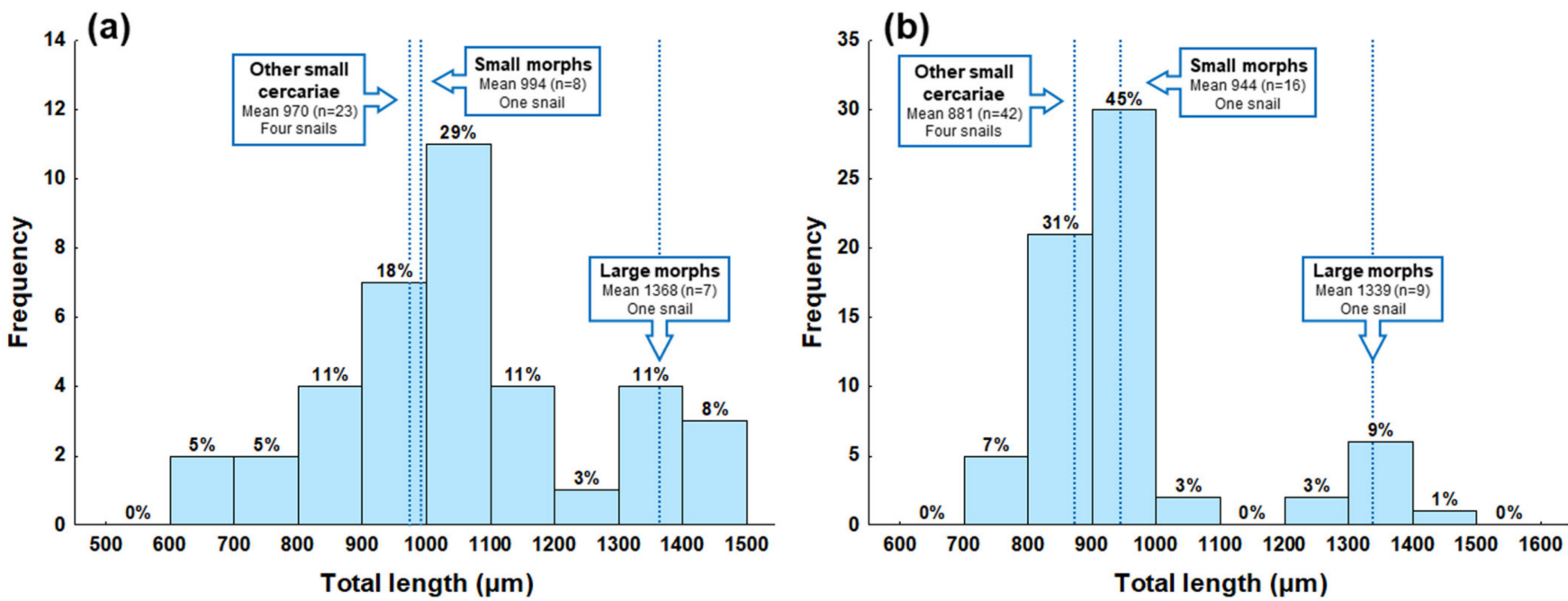

Figure A1. Frequency distribution of cercarial sizes represented by the total length (sum of lengths of body, tail stem, and furca) of Trichobilharzia sp. "peregra" isolated from naturally infected Radix balthica snails. Measurements are based on (a) live specimens and (b) formalin-fixed specimens. Boxes represent three groups of cercariae (large and small morphs, and other small cercariae) with data on the mean total length (dotted lines), number of cercariae (n), and the origin of cercariae from snail hosts.

Table A1. Comparative metrical data for live specimens of cercariae of Trichobilharzia sp. "peregra" isolated from naturally infected Radix balthica snails. Data are presented in micrometers as the mean \pm SD and range (minimum to maximum values). The width values correspond to maximum width measurements.

\begin{tabular}{|c|c|c|c|c|c|c|}
\hline Group of Cercariae & \multicolumn{2}{|c|}{ Large Morphs ${ }^{1}$} & \multicolumn{2}{|c|}{ Small Morphs 1} & \multicolumn{2}{|c|}{$\begin{array}{l}\text { Other Small } \\
\text { Cercariae }^{2}\end{array}$} \\
\hline \multirow[t]{2}{*}{ No. of Cercariae Measured } & \multicolumn{2}{|c|}{7} & \multicolumn{2}{|c|}{8} & \multicolumn{2}{|c|}{23} \\
\hline & Mean \pm SD & Range & Mean \pm SD & Range & Mean \pm SD & Range \\
\hline Total length & $1368 \pm 49$ & $1302-1420$ & $994 \pm 65$ & $901-1067$ & $970 \pm 157$ & $668-1208$ \\
\hline Body length & $340 \pm 42$ & $304-427$ & $276 \pm 20$ & $242-305$ & $272 \pm 36$ & $200-332$ \\
\hline Body width & $110 \pm 11$ & $94-127$ & $90 \pm 4$ & 85-97 & $93 \pm 10$ & 63-105 \\
\hline Tail stem length & $702 \pm 41$ & $621-745$ & $449 \pm 39$ & $401-497$ & $432 \pm 99$ & $241-564$ \\
\hline Tail stem width & $62 \pm 6$ & $54-70$ & $57 \pm 4$ & $50-62$ & $52 \pm 10$ & $22-68$ \\
\hline Furca length & $326 \pm 28$ & $276-353$ & $270 \pm 23$ & $236-292$ & $265 \pm 34$ & $184-322$ \\
\hline Head organ length & $119 \pm 9$ & $105-130$ & $93 \pm 4$ & $90-98$ & $97 \pm 9$ & $72-108$ \\
\hline Head organ width & $76 \pm 7$ & $65-84$ & $64 \pm 2$ & $61-66$ & $64 \pm 6$ & $52-80$ \\
\hline Diameter of acetabulum & $34 \pm 9$ & $26-48$ & $27 \pm 7$ & 21-39 & $34 \pm 5$ & $22-43$ \\
\hline Center of acetabulum to anterior body end & $212 \pm 29$ & $178-260$ & $165 \pm 17$ & $141-191$ & $161 \pm 27$ & $120-215$ \\
\hline Diameter of eye spot & $9 \pm 1$ & $8-10$ & $8 \pm 1$ & $7-9$ & $7 \pm 1$ & $6-9$ \\
\hline Eye spot to anterior body end & $145 \pm 15$ & $123-174$ & $124 \pm 13$ & 111-151 & $120 \pm 17$ & $81-160$ \\
\hline Body length/Body width & 3.08 & $2.81-3.36$ & 3.07 & $2.69-3.47$ & 2.96 & $2.27-3.86$ \\
\hline Body length/Tail stem length & 0.49 & $0.43-0.60$ & 0.62 & $0.53-0.76$ & 0.65 & $0.49-1.01$ \\
\hline Tail stem length/Furca length & 2.17 & $1.84-2.60$ & 1.67 & $1.57-1.88$ & 1.62 & $0.97-1.91$ \\
\hline
\end{tabular}

${ }^{1}$ Two distinct size morphs of cercariae isolated from one snail individual, and ${ }^{2}$ Cercariae isolated from four snail individuals. 
Table A2. Comparative metrical data for formalin-fixed specimens of cercariae of Trichobilharzia sp. "peregra" isolated from naturally infected Radix balthica snails. Data are presented in micrometers as the mean \pm SD and range (minimum to maximum values). The width values correspond to maximum measurements.

\begin{tabular}{|c|c|c|c|c|c|c|}
\hline Group of Cercariae & \multicolumn{2}{|c|}{ Large Morphs ${ }^{1}$} & \multicolumn{2}{|c|}{ Small Morphs ${ }^{1}$} & \multicolumn{2}{|c|}{$\begin{array}{l}\text { Other Small } \\
\text { Cercariae }^{2}\end{array}$} \\
\hline \multirow[t]{2}{*}{ No. of Cercariae Measured } & \multicolumn{2}{|c|}{9} & \multicolumn{2}{|c|}{16} & \multicolumn{2}{|c|}{42} \\
\hline & Mean \pm SD & Range & Mean \pm SD & Range & Mean \pm SD & Range \\
\hline Total length & $1339 \pm 51$ & $1270-1436$ & $944 \pm 37$ & 874-1023 & $881 \pm 66$ & 733-991 \\
\hline Body length & $278 \pm 25$ & $241-317$ & $241 \pm 30$ & $201-332$ & $223 \pm 19$ & $190-266$ \\
\hline Body width & $75 \pm 10$ & $65-87$ & $66 \pm 6$ & $54-75$ & $62 \pm 9$ & $45-78$ \\
\hline Tail stem length & $741 \pm 39$ & $680-789$ & $461 \pm 14$ & $426-481$ & $421 \pm 50$ & $320-499$ \\
\hline Tail stem width & $54 \pm 5$ & 49-64 & $47 \pm 4$ & $41-56$ & $44 \pm 5$ & $34-54$ \\
\hline Furca length & $320 \pm 17$ & $294-340$ & $242 \pm 15$ & $217-263$ & $237 \pm 22$ & $169-281$ \\
\hline Head organ length & $85 \pm 7$ & 72-94 & $74 \pm 8$ & $62-91$ & $73 \pm 6$ & 59-84 \\
\hline Head organ width & $50 \pm 6$ & $42-57$ & $45 \pm 2$ & $42-50$ & $43 \pm 4$ & $38-55$ \\
\hline Diameter of acetabulum & $29 \pm 2$ & $26-33$ & $26 \pm 3$ & 20-31 & $25 \pm 3$ & 20-33 \\
\hline Center of acetabulum to anterior body end & $167 \pm 29$ & $105-196$ & $137 \pm 17$ & $108-168$ & $134 \pm 13$ & $107-160$ \\
\hline Diameter of eye spot & $9 \pm 1$ & 8-11 & $8 \pm 1$ & 7-9 & $8 \pm 1$ & 7-9 \\
\hline Eye spot to anterior body end & $123 \pm 14$ & $104-148$ & $112 \pm 9$ & $93-130$ & $103 \pm 11$ & $80-126$ \\
\hline Body length/Body width & 3.76 & $2.97-4.65$ & 3.70 & $2.91-5.19$ & 3.71 & $2.56-5.56$ \\
\hline Body length/Tail stem length & 0.38 & $0.31-0.45$ & 0.52 & $0.45-0.74$ & 0.54 & $0.41-0.77$ \\
\hline Tail stem length/Furca length & 2.32 & $2.12-2.49$ & 1.91 & $1.77-2.11$ & 1.78 & $1.45-2.20$ \\
\hline
\end{tabular}

${ }^{1}$ Two distinct size morphs of cercariae isolated from one snail individual, and ${ }^{2}$ Cercariae isolated from four snail individuals.

\section{References}

1. Leimar, O. The evolution of phenotypic polymorphism: Randomized strategies versus evolutionary branching. Am. Nat. 2005, 165, 669-681. [CrossRef] [PubMed]

2. West-Eberhard, M.J. Phenotypic Plasticity. In Encyclopedia of Ecology; Jørgensen, S.E., Fath, B.D., Eds.; Elsevier: Amsterdam, The Netherlands, 2008; pp. 2701-2707.

3. Fox, R.J.; Donelson, J.M.; Schunter, C.; Ravasi, T.; Gaitán-Espitia., J.D. Beyond buying time: The role of plasticity in phenotypic adaptation to rapid environmental change. Phil. Trans. R. Soc. B 2019, 374, 20180174. [CrossRef]

4. Jamie, G.A.; Meier, J.I. The persistence of polymorphisms across species radiations. Trends Ecol. Evol. 2020, 35, 795-808. [CrossRef] [PubMed]

5. Ford, E.B. Genetic Polymorphism; Faber \& Faber: London, UK, 1965; p. 101.

6. Fusco, G.; Minelli, A. Phenotypic plasticity in development and evolution: Facts and concepts. Philos. Trans. R. Soc. Lond. B Biol. Sci. 2010, 365, 547-556. [CrossRef] [PubMed]

7. Pigliucci, M.; Murren, C.J.; Schlichting, C.D. Phenotypic plasticity and evolution by genetic assimilation. J. Exp. Biol. 2006, 209, 2362-2367. [CrossRef]

8. Wills, B.D.; Powell, S.; Rivera, M.D.; Suarez, A.V. Correlates and consequences of worker polymorphism in ants. Annu. Rev. Entomol. 2018, 63, 575-598. [CrossRef]

9. Frances, P.; Burnie, D. Bird: The Definitive Visual Guide; Dorling Kindersley Inc.: London, UK, 2007; p. 512.

10. Poulin, R. The evolution of life history strategies in parasitic animals. Adv. Parasitol. 1996, 37, 107-134. [CrossRef]

11. Maizels, R.M.; Kurniawan-Atmadja, A. Variation and polymorphism in helminth parasites. Parasitology 2002, 125, 25-37. [CrossRef]

12. Thompson, C.K.; Botero, A.; Wayne, A.F.; Godfrey, S.S.; Lymbery, A.J.; Thompson, R.A. Morphological polymorphism of Trypanosoma copemani and description of the genetically diverse T. vegrandis sp. nov. from the critically endangered Australian potoroid, the brush-tailed bettong (Bettongia penicillata (Gray, 1837)). Parasit. Vectors 2013, 6, 121. [CrossRef]

13. Hanzelová, V.; Oros, M.; Barčák, D.; Miklisová, D.; Kirin, D.; Scholz, T. Morphological polymorphism in tapeworms: Redescription of Caryophyllaeus laticeps (Pallas, 1781) (Cestoda: Caryophyllidea) and characterisation of its morphotypes from different fish hosts. Syst. Parasitol. 2015, 90, 177-190. [CrossRef]

14. Guo, Q.; Huang, M.; Liu, Y.; Zhang, X.; Gu, Z. Morphological plasticity in Myxobolus Bütschli, 1882: A taxonomic dilemma case and renaming of a parasite species of the common carp. Parasit. Vectors 2018, 11, 399. [CrossRef]

15. Dobson, A.; Lafferty, K.D.; Kuris, A.M.; Hechinger, R.F.; Jetz, W. Homage to Linnaeus: How many parasites? How many hosts? Proc. Natl. Acad. Sci. USA 2008, 105, 11482-11489. [CrossRef]

16. Poulin, R. Parasite biodiversity revisited: Frontiers and constraints. Int. J. Parasitol. 2014, 44, 581-589. [CrossRef] 
17. Pandian, T.J. Reproduction and Development in Platyhelminthes; CRC Press: Boca Raton, FL, USA, 2020; p. 320. [CrossRef]

18. Galaktionov, K.V.; Dobrovolskij, A. The Biology and Evolution of Trematodes: An Essay on the Biology, Morphology, Life Cycles, Transmissions, and Evolution of Digenetic Trematodes; Kluwer Academic Publishers: Dordrecht, The Netherlands, 2003 ; p. 592.

19. Soldánová, M.; Selbach, C.; Kalbe, M.; Kostadinova, A.; Sures, B. Swimmer's itch: Etiology, impact, and risk factors in Europe. Trends Parasitol. 2013, 29, 65-74. [CrossRef]

20. Jamieson, B.G.M. Schistosoma: Biology, Pathology and Control; CRC Press: Boca Raton, FL, USA, 2017; p. 523. [CrossRef]

21. Kock, S. Investigations of intermediate host specificity help to elucidate the taxonomic status of Trichobilharzia ocellata (Digenea: Schistosomatidae). Parasitology 2001, 123, 67-70. [CrossRef]

22. Poulin, R. Morphological diversification in different trematode lineages: Body size, host type, or time? Parasitology 2009, 136, 85-92. [CrossRef]

23. Hechinger, R.F.; Wood, A.C.; Kuris, A.M. Social organization in a flatworm: Trematode parasites form soldier and reproductive castes. Proc. R. Soc. B 2011, 278, 656-665. [CrossRef]

24. Garcia-Vedrenne, A.E.; Quintana, A.C.; DeRogatis, A.M.; Martyn, K.; Kuris, A.M.; Hechinger, R.F. Social organization in parasitic flatworms-four additional echinostomoid trematodes have a soldier caste and one does not. J. Parasitol. 2016, 102, 11-20. [CrossRef]

25. Poulin, R.; Kamiya, T.; Lagrue, C. Evolution, phylogenetic distribution and functional ecology of division of labour in trematodes. Parasit. Vectors 2019, 12,1-10. [CrossRef]

26. Seppälä, O.; Karvonen, A.; Valtonen, E.T. Phenotypic variation in infectivity of Diplostomum spathaceum cercariae within a population. J. Parasitol. 2007, 93, 124-1246. [CrossRef]

27. Koehler, A.V.; Springer, Y.P.; Keeney, D.B.; Poulin, R. Intra-and interclonal phenotypic and genetic variability of the trematode Maritrema novaezealandensis. Biol. J. Linn. Soc. Lond. 2011, 103, 106-116. [CrossRef]

28. Prokofiev, V.V.; Levakin, I.A.; Losev, E.A.; Zavirsky Ya, A.; Galaktionov, K.V. Clonal variability in expression of geo-and photoorientation in cercariae of Himasthla elongata (Trematoda: Echinostomatidae). Parazitologiia 2011, 45, 345-357. (In Russian)

29. Koehler, A.V.; Poulin, R. Clone-specific immune reactions in a trematode-crustacean system. Parasitology 2012, 139, 128-136. [CrossRef] [PubMed]

30. Koehler, A.V.; Springer, Y.P.; Randhawa, H.S.; Leung, T.L.F.; Keeney, D.B.; Poulin, R. Genetic and phenotypic influences on clone-level success and host specialization in a generalist parasite. J. Evol. Biol. 2012, 25, 66-79. [CrossRef]

31. Levakin, I.A.; Losev, E.A.; Nikolaev, K.E.; Galaktionov, K.V. In vitro encystment of Himasthla elongata cercariae (Digenea, Echinostomatidae) in the haemolymph of blue mussels Mytilus edulis as a tool for assessing cercarial infectivity and molluscan susceptibility. J. Helminthol. 2013, 87, 180-188. [CrossRef]

32. Louhi, K.R.; Karvonen, A.; Rellstab, C.; Jokela, J. Genotypic and phenotypic variation in transmission traits of a complex life cycle parasite. Ecol. Evol. 2013, 3, 2116-2127. [CrossRef]

33. Neves, R.H.; Costa-Silva, M.; Martinez, E.M.; Branquinho, T.B.; de Oliveira, R.M.; Lenzi, H.L.; Gomes, D.C.; Machado-Silva, J.R. Phenotypic plasticity in adult worms of Schistosoma mansoni (Trematoda: Schistosomatidae) evidenced by brightfield and confocal laser scanning microscopies. Mem. Inst. Oswaldo Cruz 2004, 99, 131-136. [CrossRef]

34. Mati, V.L.T.; Freitas, R.M.; Bicalho, R.S.; Melo, A.L. Phenotypic plasticity of male Schistosoma mansoni from the peritoneal cavity and hepatic portal system of laboratory mice and hamsters. J. Helminthol. 2015, 89, 294-301. [CrossRef]

35. Bayne, C.J.; Grevelding, C.G. Cloning of Schistosoma mansoni sporocysts in vitro and detection of genetic heterogeneity among individuals within clones. J. Parasitol. 2003, 89, 1056-1060. [CrossRef]

36. Théron, A.; Sire, C.; Rognon, A.; Prugnolle, F.; Durand, P. Molecular ecology of Schistosoma mansoni transmission inferred from the genetic composition of larval and adult infrapopulations within intermediate and definitive hosts. Parasitology 2004, 129, 571-585. [CrossRef]

37. Shalaby, I.; Gherbawy, Y.; Banaja, A. Genetic diversity among Schistosoma mansoni population in the western region of Saudi Arabia. Trop. Biomed. 2011, 28, 90-101.

38. Korsunenko, A.; Chrisanfova, G.; Lopatkin, A.; Beer, S.A.; Voronin, M.; Ryskov, A.P.; Semyenova, S.K. Genetic differentiation of cercariae infrapopulations of the avian schistosome Trichobilharzia szidati based on RAPD markers and mitochondrial cox1 gene. Parasitol. Res. 2012, 110, 833-841. [CrossRef]

39. Gu, M.J.; Li, Y.W.; Emery, A.M.; Li, S.Z.; Jiang, Y.Z.; Dong, H.F.; Zhao, Q.P. The genetic variation of different developmental stages of Schistosoma japonicum: Do the distribution in snails and pairing preference benefit the transmission? Parasit. Vectors 2020, 13, 360. [CrossRef]

40. Mitta, G.; Adema, C.M.; Gourbal, B.; Loker, E.S.; Theron, A. Compatibility polymorphism in snail/schistosome interactions: From field to theory to molecular mechanisms. Dev. Comp. Immunol. 2012, 37, 1-8. [CrossRef]

41. Lima, M.G.; Montresor, L.C.; Pontes, J.; Augusto, R.C.; da Silva, J.P.; Thiengo, S.C. Compatibility polymorphism based on long-term host-parasite relationships: Cross talking between Biomphalaria glabrata and the trematode Schistosoma mansoni from endemic areas in Brazil. Front. Immunol. 2019, 10, 328. [CrossRef]

42. Pino, L.A.; Matinella, L.; Morales, G. The size polymorphism of the cercariae of a Venezuelan strain of Schistosoma mansoni. Rev. Soc. Bras. Med. Trop. 1999, 32, 443-446. [CrossRef]

43. Jouet, D.; Skírnisson, K.; Kolářová, L.; Ferté, H. Molecular diversity of Trichobilharzia franki in two intermediate hosts (Radix auricularia and Radix peregra): A complex of species. Infect. Genet. Evol. 2010, 10, 1218-1227. [CrossRef] 
44. Born-Torrijos, A.; Paterson, R.A.; van Beest, G.S.; Schwelm, J.; Vyhlídalová, T.; Henriksen, E.H.; Knudsen, R.; Kristoffersen, R.; Amundsen, P.-A.; Soldánová, M. Temperature does not influence functional response of amphipods consuming different trematode prey. Parasitol. Res. 2020, 119, 4271-4276. [CrossRef]

45. Born-Torrijos, A.; Paterson, R.A.; van Beest, G.S.; Vyhlídalová, T.; Henriksen, E.H.; Knudsen, R.; Kristoffersen, R.; Amundsen, P.-A.; Soldánová, M. Cercarial behaviour alters the consumer functional response of three-spined sticklebacks. J. Anim. Ecol. 2021, 90, 978-988. [CrossRef]

46. Esch, G.W.; Curtis, L.A.; Barger, M.A. A perspective on the ecology of trematode communities in snails. Parasitology 2001, 123, 57-75. [CrossRef]

47. Combes, C.; Bartoli, P.; Théron, A. Trematode Transmission Strategies. In The Behavioural Ecology of Parasites; Lewis, E.E., Campbell, J.F., Sukhdeo, M.V.K., Eds.; CABI: Wallingford, UK, 2002; pp. 1-12. [CrossRef]

48. Morley, N.J. Cercariae (Platyhelminthes: Trematoda) as neglected components of zooplankton communities in freshwater habitats. Hydrobiologia 2012, 691, 7-19. [CrossRef]

49. Pietrock, M.; Marcogliese, D.J. Free-living endohelminth stages: At the mercy of environmental conditions. Trends Parasitol. 2003, 19, 293-299. [CrossRef]

50. Thieltges, D.W.; Jensen, K.T.; Poulin, R. The role of biotic factors in the transmission of free-living endohelminth stages. Parasitology 2008, 135, 407-426. [CrossRef]

51. Combes, C.; Fournier, A.; Moné, H.; Théron, A. Behaviours in trematode cercariae that enhance parasite transmission: Patterns and processes. Parasitology 1994, 109, 3-13. [CrossRef]

52. Haas, W. Parasitic worms: Strategies of host finding, recognition and invasion. Zoology 2003, 106, 349-364. [CrossRef]

53. Horák, P.; Mikeš, L.; Lichtenbergová, L.; Skála, V.; Soldánová, M.; Brant, S.V. Avian schistosomes and outbreaks of cercarial dermatitis. Clin. Microbiol. Rev. 2015, 28, 165-190. [CrossRef]

54. Soldánová, M.; Selbach, C.; Sures, B. The early worm catches the bird? Productivity and patterns of Trichobilharzia szidati cercarial emission from Lymnaea stagnalis. PLoS ONE 2016, 11, e0149678. [CrossRef]

55. Ginetsinskaya, T.A. Glycogen in cercariae, and the dependence of its distribution on the specific characters of the parasite. Dokl. Akad. Nauk SSSR 1960, 135, 1012-1015.

56. Ginetsinskaya, T.A. Trematodes; Their Life-Cycles, Biology and Evolution; Amerind Publ. Co., Pvt. Ltd.: New Delhi, India, 1988; p. 559.

57. Morley, N.J. Cercarial swimming performance and its potential role as a key variable of trematode transmission. Parasitology 2020, 147, 1369-1374. [CrossRef]

58. Lawson, R.J.; Wilson, R.A. The survival of the cercariae of Schistosoma mansoni in relation to water temperature and glycogen utilization. Parasitology 1980, 81, 337-348. [CrossRef]

59. Lowenberger, C.A.; Rau, M.E. Plagiorchis elegans: Emergence, longevity and infectivity of cercariae, and host behavioural modifications during cercarial emergence. Parasitology 1994, 109, 65-72. [CrossRef] [PubMed]

60. Pechenik, J.A.; Fried, B. Effect of temperature on survival and infectivity of Echinostoma trivolvis cercariae: A test of the energy limitation hypothesis. Parasitology 1995, 111, 373-378. [CrossRef]

61. Karvonen, A.; Paukku, S.; Valtonen, E.T.; Hudson, P.J. Transmission, infectivity and survival of Diplostomum spathaceum cercariae. Parasitology 2003, 127, 217-224. [CrossRef] [PubMed]

62. Johnson, P.T.J.; Thieltges, D.W. Diversity, decoys and the dilution effect: How ecological communities affect disease risk. J. Exp. Biol. 2010, 213, 961-970. [CrossRef]

63. Johnson, P.T.J.; Dobson, A.; Lafferty, K.D.; Marcogliese, D.J.; Memmott, J.; Orlofske, S.A.; Poulin, R.; Thieltges, D.W. When parasites become prey: Ecological and epidemiological significance of eating parasites. Trends Ecol. Evol. 2010, $25,362-371$. [CrossRef]

64. Keesing, F.; Belden, L.K.; Daszak, P.; Dobson, A.; Harvell, C.D.; Holt, R.D.; Hudson, P.; Jolles, A.; Jones, K.E.; Mitchell, C.E.; et al. Impacts of biodiversity on the emergence and transmission of infectious diseases. Nature 2010, 468, 647-652. [CrossRef]

65. Goedknegt, A.; Welsh, J.; Thieltges, D.W. Parasites as Prey; John Wiley \& Sons, Ltd.: Hoboken, NJ, USA, 2012; p. 7. [CrossRef]

66. Stanicka, A.; Migdalski, Ł.; Szopieray, K.; Cichy, A.; Jermacz, Ł.; Lombardo, P.; Żbikowska, E. Invaders as diluents of the cercarial dermatitis etiological agent. Pathogens 2021, 10, 740. [CrossRef]

67. Kaplan, A.T.; Rebhal, S.; Lafferty, K.D.; Kuris, A.M. Small estuarine fishes feed on large trematode cercariae: Lab and field investigations. J. Parasitol. 2009, 95, 477-480. [CrossRef]

68. Orlofske, S.A.; Jadin, R.C.; Johnson, P.T.J. It's a predator-eat-parasite world: How characteristics of predator, parasite and environment affect consumption. Oecologia 2015, 178, 537-547. [CrossRef]

69. Catania, S.V.; Koprivnikar, J.; McCauley, S.J. Size-dependent predation alters interactions between parasites and predators. Can. J. Zool. 2016, 94, 631-635. [CrossRef]

70. Welsh, J.E.; Hempel, A.; Markovic, M.; Van der Meer, J.; Thieltges, D.W. Consumer and host body size effects on the removal of trematode cercariae by ambient communities. Parasitology 2019, 146, 342-347. [CrossRef]

71. Gilbert, S.F. Ecological developmental biology: Developmental biology meets the real world. Dev. Biol. 2001, 233, 1-12. [CrossRef]

72. Loker, E.S. A comparative study of the life-histories of mammalian schistosomes. Parasitology 1983, 87, 343-369. [CrossRef]

73. Gérard, C.J.; Moné, H.; Théron, A. Schistosoma mansoni-Biomphalaria glabrata: Dynamics of the sporocyst population in relation to the miracidial dose and the host size. Can. J. Zool. 1993, 71, 1880-1885. [CrossRef] 
74. Podhorský, M.; Hůzová, Z.; Mikeš, L.; Horák, P. Cercarial dimensions and surface structures as a tool for species determination of Trichobilharzia spp. Acta Parasitol. 2009, 54, 28-36. [CrossRef]

75. Poulin, R. Global warming and temperature-mediated increases in cercarial emergence in trematode parasites. Parasitology 2006, 132, 143-151. [CrossRef]

76. Horák, P.; Kolářová, L.; Adema, C.M. Biology of the schistosome genus Trichobilharzia. Adv. Parasitol. 2002, 52, 155-233. [CrossRef]

77. Grevelding, C.G. Genomic instability in Schistosoma mansoni. Mol. Biochem. Parasitol. 1999, 101, 207-216. [CrossRef]

78. Semyenova, S.K.; Khrisanfova, G.G.; Korsunenko, A.V.; Voronin, M.V.; Beer, S.V.; Vodyanitskaya, S.V.; Serbina, E.A.; Yurlova, N.I.; Ryskov, A.P. Multilocus variation in cercariae, parthenogenetic progeny of different species of the class Trematoda. Dokl. Biol. Sci. 2007, 414, 235-238. [CrossRef]

79. Galaktionov, N.K.; Podgornaya, O.I.; Strelkov, P.P.; Galaktionov, K.V. Genomic diversity of cercarial clones of Himasthla elongata (Trematoda, Echinostomatidae) determined with AFLP technique. Parasitol. Res. 2016, 115, 4587-4593. [CrossRef]

80. Minchella, D.J.; Sollenberger, K.M.; Pereira de Souza, C. Distribution of schistosome genetic diversity within molluscan intermediate hosts. Parasitology 1995, 111, 217-220. [CrossRef] [PubMed]

81. Davies, C.M.; Webster, J.P.; Krüger, O.; Munatsi, A.; Ndamba, J.; Woolhouse, M.E. Host-parasite population genetics: A cross-sectional comparison of Bulinus globosus and Schistosoma haematobium. Parasitology 1999, 119, 295-302. [CrossRef] [PubMed]

82. Soldánová, M.; Georgieva, S.; Roháčová, J.; Knudsen, R.; Kuhn, J.A.; Henriksen, E.H.; Siwertsson, A.; Shaw, J.C.; Kuris, A.M.; Amundsen, P.-A.; et al. Molecular analyses reveal high species diversity of trematodes in a sub-Arctic lake. Int. J. Parasitol. 2017, 47, 327-345. [CrossRef] [PubMed]

83. Reier, S.; Haring, E.; Billinger, F.; Blatterer, H.; Duda, M.; Gorofsky, C.; Grasser, H.P.; Heinisch, W.; Hörweg, C.; Kruckenhauser, L.; et al. First confirmed record of Trichobilharzia franki Müller \& Kimmig, 1994, from Radix auricularia (Linnaeus, 1758) for Austria. Parasitol. Res. 2020, 119, 4135-4141. [CrossRef]

84. Helmer, N.; Blatterer, H.; Hörweg, C.; Reier, S.; Sattmann, H.; Schindelar, J.; Szucsich, N.U.; Haring, E. First record of Trichobilharzia physellae (Talbot, 1936) in Europe, a possible causative agent of cercarial dermatitis. Pathogens 2021, 10, 1473. [CrossRef]

85. Brant, S.V.; Loker, E.S. Molecular systematics of the avian schistosome genus Trichobilharzia (Trematoda: Schistosomatidae) in North America. J. Parasitol. 2009, 95, 941-963. [CrossRef]

86. Abràmoff, M.D.; Magalhães, P.J.; Ram, S.J. Image processing with ImageJ. Biophotonics Int. 2004, 11, 36-42. 